\title{
Voices From The Land of The Dispossessed: a Glimpse on Herta Muller's Novels
}

\author{
Mrs. S. PUNITHA M.A., M.Phil. \\ Assistant Professor of EnglishPG \& Research Department of EnglishVellalar College for Women, Thindal, \\ Erode-12.
}

\begin{abstract}
Individual Identity is a highly sorted out factor when there are atrocities perpetrated in the name of nation and race. This identity - seeking tendency prevails in each and every human leading them to explore themselves. A study of Herta Muller's fictional works brings us closer to the divided post-war world during the cold war. It places us amidst a complex, and splintered literary history, unexplored in Western Europe and the U. S., several from our awareness lost and censored behind the Iron Curtain.
\end{abstract}

Keywords:- atrocities, post-war world, cold war, splintered, Iron Curtain

“A work of rare force, a feat of sustained and overpowering poetry...Müller hasthe ability to distil concrete objects into language of the greatest intensity and to sear these objects on to the reader's mind".

The New York Times

The Nobel Committee described her as a writer 'who, with the concentration of poetry and the frankness of prose, depicts the landscape of the dispossessed'. Müller's works depicts the persecution of Romanian ethnic German by Stalinist Soviet occupying forces in Romania and the Soviet - imposed communist regime of Romania.According to the Nobel Committee, Herta Müller, who charted the hardships and humiliations of Nicolae Ceausescu's brutal regime, won the 2009 Nobel Prize in Literature for depicting the landscape of the dispossessed.

\section{"What can't be said can be written. Because writing is a silent act, a labor from the head to the hand"}

- Herta Müller.

Born on August 17, 1953, in the German-speaking village of Nitchidorf, in the Romanian Banat in Western Romania, Herta Müller left her village to study German and Romanian literature at the University of Timisoara. There she became part of the Aktionsgruppe Banat, a group of idealistic Romanian-German writers seeking freedom of expression under the Ceausescu dictatorship. After completing her studies, she was employed as a translator in an engineering factory, but was dismissed for her refusal to cooperate with the Securitate. She had become an internationally well-known author since the early 1990s when her works such as The Passport, The Land of Green Plums, Travelling on One Leg, The AppointmentandThe Hunger Angel were translated into English. Though she has about 20 books to her credit, only 5 are translated into English. Besides English, her works have been translated into more than 20 languages. She has received over 20 awards which include the 1994 Kleist Prize, the 1995 AristeionPrize (European Literary Prize) for Herztier, the 1998 International IMPAC Dublin Literary Award for The Land of Green Plums, and the 2009 Franz Werfel Human Rights Award for her novel EverythingI Possess I Carry With Me (The Hunger Angel).

Müller started her career in 1982 with a collection of short stories entitled Niederungen(English Nadirs in 1999). Two years later, this was followed by Druckender Tango (Oppressive Tango). In these two works Müller depicted the hypocrisy of village life and its ruthless oppression of nonconformists. She also portrayed the zealously fascist mentality of the German minority, its tolerance and corruption. Not surprisingly, she was sharply criticized at home for destroying the idyllic image of German rural life in Romania.

Later Müller migrated to the West with her husband, Richard Wagner, who is also a novelist and essayist. The Passport (1989), her first translated novel into English, portrays the efforts of a Romanian-German peasant family to get passports to leave the country who were unable to live under the brutal hardships of Nicolae Ceausescu. Like her earlier works it exposes the brutal corruption of the village by showing how its officials, from postmaster to priest, demanded ever more material and sexual favours from those petitioning to leave the country.

The Land of Green Plums (1996) deals with "the issues faced by the writers and their relationship with the government censorship of their works". It is Müller's richest portrayal to the date of life in the Romanian dictatorship where the novelist links the repressive childhood of her narrator with the brutal oppression of the state. The novel opens in a women's university dormitory in Nicolae Ceausescu's Romania, where Lola, a poor girl from the provinces, has come to study Russian. In a Communist country short on consumer goods, Lola and 
her roommates dream of whisper-thin nylon stockings while making to do with what they have. Lola, unprepared for city life by her village childhood, has brutal sexual encounters, hangs herself with a bent and is posthumously expelled from the Communist Party.

Müller's The Land of Green Plums, studies the effect of political persecution on individuals and how that experience and its memories, in turn, shape the lives of those affected.The narrator of the novel is one of her roommates, soon herself an object of political suspicion, so that when she finally leaves the university, packing her pot of mascara, she finds an unpleasant surprise in her bed. When she picks up the blanket to pull off the cover, she finds a pig's ear that is sewed in the middle of the sheet like a button. Later she learns that this is the girls' way of saying farewell.

Müller lets her plot develop around simple people living uneventful lives. It is because her characters are so plebian, that the tragedy strikes as particularly harsh. With no legitimate claim to martyrdom, the events circumscribing the lives of the narrator and her friends accentuate the trauma as suffered by a nation and that which unapologetically wields the ultimate power to transform identities.

According to Larry Wolff, "The Land of Green Plums is a graphically observed detail in which the author seeks to create a sort of poetry out of the spiritual and material ugliness of life in Communist Romania". The narrator watches the Romanian police guards in the streets of the city as they greedily pocket green plums. She had been warned by her father not to eat green plums as it is dangerous. But the guards do not hesitate. She also watches the guards grabbing the young women in the streets. After witnessing such things, she even thinks that one of these men must have followed Lola and mauled her with the greedy desire of a starved dog. When the narrator ponders Lola's pathetic fate, the novel encompasses not only the political persecution of dissidents and the harassment of a national minority but also the particular kinds of oppression and vulnerability that women experience under a regime of policemen. In the end, the narrator decides to kill herself, as Lola did, but to immigrate to Germany, as most of Romania's Germans have done, both before and since the fall of Ceausescu in 1989.

The Land of Green Plums also addresses issues such as vampirish complicity in the bloody rituals of an oppressive regime, whose hungry subjects, whether stealing fresh offal or green plums, ingest political poisons with historically protracted, corrosive consequences. Through this novel, Müller conveys certain sadness over the historical implications of emigration, the impending doom of her own native culture and society. She also offers a potent and repellent depiction of the world she left behind in Romania. As the novel is based on a close friend from Aktionsgruppe Banat and written after the deaths of two friends in which Müller suspected the Securitate's involvement, she dedicated it to Romanian friends who were killed under Ceausescu's rule.

Characterized by the same sense of profound isolation found in Müller's The Land of Green Plums, Travelling on One Leg is a poignant exploration of exile, homeland and identity. It traces the disorientations of exile through the troubled mind of the protagonist Irene, a 30 year-old woman whose circumstances are partly drawn from Müller's life. Like her, Irene, a fragile woman born to a German family in Romania, emigrates to West Berlin from "the other country" (Romania is never identified directly in the novel). Certain elements introduced in the first chapter - bushes, fingernails, crumbling earth, the sucking of the tide - become the symbols of intense sexual longing that reappear throughout the book.

The narration is spare to the point of madness, a poetry of anguish built upon images of division or inversion - 'Irene walked on her head'. When she is photographed, it seems to her that the picture shows "the other Irene", an alter ego that shadows her life; when she walks through an apartment for the first time, the rooms are said to walk through her instead. Irene's immediate reason for emigrating is to be with Franz, a drunken tourist from Marburg whom she meets at a beachside café in Romania. When she reaches Germany, Irene finds herself drawn into intimate relationships, not only with Franz but also with his friends, Thomas and Stefan. All three men, especially Thomas, seem to be miserable in one way or another. Irene can't understand how a person would go about being sad in the disordered West; in "the other country", she says, the reasons for unhappiness were always obvious.

Despite being born to a German family, Irene's place in Germany is as a recent émigré and an unassimilated Romanian German. She feels neither longing for Romania nor any comfort in her newly adopted Germany. Politically and socially isolated, Irene moves within the emotional orbit of these three men, while at the same time moving between West Berlin, Marburg and Frankfurt, taking a dissonant journey within strange yet familiar territory. The action in this volume may be slight, but Irene's innermost consciousness - where the political has indeed become the personal - is magnificently portrayed.

Müller's another powerful novel The Appointment (2001) is about a Romanian woman who sews notes, saying "Marry Me" into suits of men bound for Italy. The thuggery of the government forms a backdrop to the novel. Writing in The New York Times Book Review, Peter Filkins describes, The Appointment as a backdrop to the brutality and betrayal with which people treat one another in their everyday lives, be they spouses, family members or the closest of friends. 
'I no longer know, either, how long we travelled. I thought travelling for a long time meant getting far away. As long as we're travelling, nothing can happen to us. All is well, as long as we're travelling'.-The Appointment, Herta Müller.

The novel goes into great detail about living under a stagnated dictatorship. The unnamed narrator contemplates the innumerable ways in which the treachery of the government infects its citizens. The entire novel -takes place during the unnamed narrator's tram ride to her appointment. The tram ride from the seventh floor apartment she shares with her second husband, the alcoholic Paul, until she misses her stop and gets off on the wrong street; a tram ride that takes about ninety minutes and for which she's risen particularly early.

The tram ride to her appointment with Major Albu seems to trigger thoughts of just about everything in our narrator, expressed as a jumbled interior monologue, and the reader is privy to what seems to be her entire life. She remembers her father's indiscretions with a person Müller calls "the woman with the braid" and how our narrator wished to take that woman's place; she remembers her good friend, Lilli, who was shot and killed while trying to escape across the border to Hungary with her lover, a sixty-six year old military officer; she remembers her own indiscretions with Nelu, the garment factory supervisor whom she had a brief affair, then rebuffed, leading him to betray her; she remembers how she net her current husband, Paul, at a flea market where she sold the wedding ring her first husband had given her; she remembers her first husband, who betrayed her grandparents; she remembers her former father-in-law, a man she refers to as "the Perfumed Commissar", who dispatched her grandparents to a forced labor camp.

"I myself am nothing, apart from being summoned", says the narrator as she rides the tram to her interrogation by the Securitate. There her interrogator, Major Albu, places a wet kiss on her hand before questioning her relentlessly for hours. These sessions, however do not happen on a regular schedule, but at Albu's whim, thus forcing the narrator to live a life in which she fears being called in on any given day, never knowing if she will be arrested for good.

With the sceptre of the regime constantly hovering over her, it is no surprise that the narrator can trust no one. Even love suffers under such conditions. Often, she has to lie or keep her mouth shut to protect the people whom she loves most. She realizes that in the world, no bond is unbreakable, no loyalty is lasting, and no future is certain. Instead, life amounts to a sequence of arbitrary episodes, each undermining the other. Because of this, her private effort to impose order on a wide array of losses amounts to a political stance in itself. The narrator's isolation and the numbing way in which she walks through life while wondering, is more a test of endurance than a pleasure. The novel follows the twists and turns of the narrator's memories and consciousness as she thinks of a world in which 'happiness had become a liability', and even 'tenderness has its own meshes'.

Ms. Müller,intense and birdlike, has a new novel out, called The Hunger Angel, signals a bit of a departure from her earlier work. Though similar in subject matter, it looks beyond her own experience to a trauma endured by her parent's generation. It portrays the persecution of ethnic Germans in Romania by the Stalinist regime of the Soviet Union and deals with the deportation of Romanian Germans to a Gulag concentration camp by Soviet occupying forces as an example for the fate of German population in Transylvania after World War II. It is about the journey of a 17-year old boy Leo Auberg who is deported to the Soviet concentration camp to live long five years of 'superhuman inhumanities'.

Müller wrote this novel when she was inspired by the experience of poet Oskar Pastior, the Romanianborn German poet and translator who wanted to write a book on the sufferings in the Gulag but died in 2006. His oral memories Müller had made notes of, but also by what happened to her own mother who also lived in the Concentration Camp of Gulag Archipelago.

'I know you'll come back'. These are the words the grandmother of seventeen-year-old Leopold Auberg says to him the night he is collected by Russian soldiers for deportation to a labor camp in the Ukraine. From the very first page of this compelling new novel it becomes clear that Müller is an author who wields an extraordinary power over words. Equally astonishing is her convincing handling of such a serious subject: extensive research and collaboration with the late Romanian-German poet Oskar Pastior about his experiences in the Gulag have given this work a life force of its own.

As the reader joins the young narrator his family is helping him pack his few belongings together into an old gramophone case, trying to overcome their fear and helplessness at his departure. He is herded onto a cattle train with other camp internees and undergoes the grueling and exhausting journey to the Gulag. Müller has distilled Leo's struggle into words of breathtaking intensity that take us on a journey far beyond the Gulag and into the depths of one man's soul. Once in the camp, the stereotypical issues the reader may expect to be confronted with are barely mentioned, here the focus is on the smaller - and at first glance insignificant - details which threaten the internees' dignity and emphasize the control they have lost over their lies.

Most startling is the way in which the author subverts the reader's conceptions of what would be imagined to be the worst elements, such as the unrelenting hunger which consumes Leo: ultimately this is what keeps him alive, acting as his connection with the world. Hunger becomes an insatiable angel who haunts the camp, but also a bare-knuckled sparring partner, delivering blows that keep Leo feeling the rawest connection to 
life.When they are released from the camp the reader expects elation, but instead they are frightened: despite its harsh and bleak conditions the camp has become their world, its walls their safety, its oppressions their routines.

Echoes of Kafka, a Jewish novelist and short-story writer, whose disturbing, symbolic fiction, written in German, prefigured the oppression and despair of the late $20^{\text {th }}$ century, can be found throughout Herta Müller's life and work. Like Kafka writing German in Bohemia, she left as a double outsider, a writer evoking alienation in a minority language. Müller has a highly individual voice, and this novel, which also shines a light on a fascinating but still neglected aspect of German history, deserves to be brought to the attention of an international readership. The language is poetic and masterful, but also joyous in its simplicity and imagery: a young woman in the camp - who had been discovered through the footprints outside her hideaway back home claims that she will never forgive the snow. Every other substance would have swallowed the evidence of her existence - water, sand, dirt - but the freshly fallen snow can never be a silent accomplice.

Müller's intense sufferings distilled her vision as an artist. Her works are characterized by pure, poetic language and metonymic metaphor that recur and evolve throughout her tales. The oppressiveness of theme is alleviated by the beauty of her prose and the flashes of humor behind some of her imagery. Thus, HertaMüller, came out as a German's literary comet and her award coincides with the anniversary of the fall of the Communism in Europe.

\section{WORK CITED:}

[1] Filkins, Peter. "Herta Müller: Betrayal as a Way of Life". The New York Times. October 21, 2001.

[2] Müller, Herta. Travelling on One Leg. Illinois: Northwestern University Press. 1998. Print.

[3] ---.The Appointment. London: Portbello. 2001. Print.

[4] ---. The Passport. London: Serpent's Tail. 2009. Print.

[5] ---. The Hunger Angel. New York: Metropoliton.2009.Print.

[6] ---. The Land of Green Plums. Picador: New York. 2010. Print.

[7] Nobel Citation. http://news.yahoo.com/s/ap/20091008/ap en ot/eunobel literature. Nobel Committee. The Hindu, October 9, 2009: 11.

[8] Verlag, Carl Hanser. New Books in German: A Selection from Austria, Germany and Switzerland. Autumn 2013. Issue 34.

[9] Wolff, Larry. "Herta Müller: Strangers in a Strange Land". New York Times Book Review. December 1, 1996. 